\title{
Corporate Social Responsibility, Corporate Governance dan Manajemen Laba pada Perusahaan Manufaktur di Indonesia Tahun 2015-2019
}

\author{
Cahyatih Kumandang* \\ Program Studi Magister Manajemen, Sekolah Tinggi Manajemen PPM \\ Jl. Menteng Raya No.9, Kb. Sirih, Kec. Menteng, Kota Jakarta Pusat, Jakarta, Indonesia \\ cahyatih@gmail.com \\ Nora Sri Hendriyeni \\ Program Studi Magister Manajemen, Sekolah Tinggi Manajemen PPM \\ J1. Menteng Raya No.9, Kb. Sirih, Kec. Menteng, Kota Jakarta Pusat, Jakarta, Indonesia \\ nora.hendriyeni@gmail.com
}

Diterima: 09-02-2021

Disetujui: $16-06-2021$

Dipublikasi: 30-06-2021

\begin{abstract}
ABSTRAK
Penelitian ini bertujuan untuk mengetahui bagaimana pengaruh Corporate Social Responsibility (CSR) dan Corporate Governance atau Tata Kelola terhadap praktik manajemen laba. CSR diproksikan dengan award CSR dan Corporate Governance dengan award GCG. Manajemen laba diukur dengan discretionary accrual dan manajemen laba riil yang dilakukan melalui aliran operasi kas. Populasi dalam penelitian ini adalah seluruh perusahaan manufaktur yang terdaftar di Bursa Efek Indonesia yang laporan keuangannya tersedia lengkap selama periode penelitian yaitu tahun 2015-2019. Hasil penelitian ini menunjukkan bahwa GCG berpengaruh negatif meskipun tidak signifikan terhadap praktik manajemen laba akrual dan manajemen laba riil melalui aliran operasi kas, sedangkan CSR berpengaruh negatif terhadap praktik manajemen laba akrual dan berpengaruh positif terhadap praktik manajemen laba riil melalui aliran operasi kas dan keduanya tidak berpengaruh secara signifikan.
\end{abstract}

Kata Kunci:

Manajemen Laba; Award; Tata Kelola; CSR.

\begin{abstract}
This study aims to see how the influence of Corporate Social Responsibility (CSR) and Corporate Governance on earnings management practices. CSR is proxied by CSR award and Corporate Governance by GCG award. Earnings management is measured by discretionary accrual and real earning management through cash flow operations. The population in this study is all manufacture companies that listed in Indonesian Stock Exchange (BEI) which their financial reports are available completely during the study period, which is from 2015-2019. This study results shows that GCG has negative impact to accrual earnings management and real earnings management through cash flow operation even though it's not significant, meanwhile CSR has negative impact to accrual earnings management and positive impact to real earnings management through cash flow operation and they're not significant.
\end{abstract}

Keywords:

Earnings Management; Awards; Governance; CSR. 


\section{PENDAHULUAN}

Maraknya kasus manipulasi laporan keuangan yang terjadi di Indonesia beberapa tahun terakhir telah berhasil menarik perhatian khalayak umum dan menyebabkan investor di perusahaan yang bersangkutan menga-lami kerugian. Contoh yang belum lama terjadi menimpa dua Badan Usaha Milik Negara (BUMN), yaitu Asuransi Jiwasraya dan Garuda Indonesia. Kedua kasus ini memberikan gambaran bagaimana akibat dari tata kelola perusahaan yang buruk.

Menurut Ketua Umum Ikatan Akuntan Publik Indonesia, Tarkosunaryo, dua kasus BUMN tersebut memiliki perbedaan mendasar. Pada kasus Asuransi Jiwasraya, Kantor Akuntan Publik (KAP) yang mengaudit, yaitu PwC, sudah memberikan opini yang tepat yakni "Wajar Dengan Pengecualian" karena pada saat audit ditemukan bahwa ekuitas perseroan surplus sebesar Rp. 5,6 triliun namun ada kekurangan cadangan premi sebesar Rp. 7,7 triliun. Jiwasraya tidak menghiraukan opini ini dan tidak memperbaiki laporan keuangannya, serta tidak ada audit kedua (Kumparan, 2020).

Pada kasus Garuda, manajemen perusahaan dan KAP yang mengaudit, yaitu KAP Tanubrata, Sutanto, Fahmi, Bambang \& Rekan, sama-sama bersalah karena menyetujui laporan keuangan yang mengakui pendapatan atas transaksi pengalihan hak kepada pihak lain. Otoritas Jasa Keuangan dan Kementerian Keuangan menyatakan hal ini tidak tepat dan memberikan sanksi kepada Garuda dan auditor yang mengaudit. Laporan Keuangan Garuda yang sudah diumumkan ke publik dianulir dan Garuda langsung merevisinya serta menyajikan ulang kembali (restatement) laporan keuangannya (Pratama, 2019).

Dua kasus tersebut adalah bentuk praktik manajemen laba yang dapat menyesatkan para investor dan pemangku kepentingan karena laporan keungan yang disajikan tidak mencerminkan kondisi sebenarnya atau dapat dikatakan laporan keuangannya berkualitas buruk. Metode ini merupakan tindakan manipulatif yang sengaja dilakukan untuk mendapat keuntungan. Manajemen laba mendapat perhatian banyak pihak karena menyebabkan turunnya kualitas laporan keuangan, sementara di pihak lain manajer mendapat keuntungan pribadi yang meningkat. Guna mengatasi hal ini, peme-rintah Indonesia telah mengeluarkan aturan mengenai tata kelola perusahaan yang baik atau Good Corporate Governance (GCG) yang wajib diterapkan oleh seluruh perusahaan.

GCG mensyaratkan perusahaan untuk mengelola perusahaannya sesuai dengan prinsip-prinsip tata kelola perusa-haan yang baik sesuai dengan peraturan perundang-undangan dan etika perusahaan (Negara, 2011). Lima prinsip GCG, yaitu transparansi, akuntabilitas, pertanggung-jawaban, kemandirian, dan kesetaraan dan kewajaran.

Dewasa ini perusahaan tidak hanya dituntut untuk mendapat keuntungan yang besar untuk dapat tetap bertahan, tetapi juga harus menunjukkan bahwa perusahaan dalam menjalankan usahanya selalu mem-perhatikan dan mengedepankan etika bisnis (Ameer, 2013). Hubungan antara GCG dan CSR terletak pada prinsip "pertanggung-jawaban" di mana penekanannya pada para pemangku kepentingan. Perusahaan sadar bahwa dalam kegiatan sehari-harinya sering memberi dampak yang harus ditanggung 
oleh pemegang kepentingan mereka dan memberikan nilai tambah bagi mereka. Dengan demikian penerapan CSR merupakan salah satu bentuk implementasi prinsip GCG.

Transparansi, keterbukaan, dan akurasi dalam memberikan informasi kepada para pemangku kepentingan secara tepat waktu telah menarik perhatian dari berbagai institusi untuk meilai dan memberikan penghargaan (award) kepada perusahaan yang telah menjalankan prinsip GCG dengan baik. Di Indonesia ada banyak ajang award namun penulis menilai dua jenis award yang dipilih sebagai variabel untuk praktik GCG dan CSR dalam penelitian ini adalah yang paling tepat karena kriteria penilaiannya sesuai dengan konsep penelitian dan penye-lenggaraannya dilangsungkan secara berkala, yaitu satu tahun sekali dan diselenggarakan oleh institusi pendidikan yang kredibel. Umumnya ajang award yang diselenggarakan oleh institusi yang kredibel memberikan persyaratan yang ketat bagi perusahaan yang akan mengikutinya dan seleksi pemilihan pemenangnya juga dilakukan secara ketat berdasarkan kriteria-kriteria yang telah ditetapkan.

Kriteria penilaian award CSR yang diselenggarakan oleh Centre for Entrepreneur-ship, Change and Third Sector (CECT) - Universitas Trisakti yang dipakai dalam penelitian ini sudah memuat kriteria pengungkapan CSR atau CSR Disclosure (CSRD) dan penerapan tata kelola yang baik (GCG). Begitu pula dengan award GCG yang diselenggarakan oleh Indonesian Institute for Corporate Directorship (IICD), kriteria penilaiannya sudah memiliki semua unsur tata kelola yang baik dan mengadopsi metode ASEAN Corporate Governance Scorecard yang dikeluarkan oleh Organization for Economic Corporation and Development (OECD), serta mempertimbangkan kasus korupsi yang melibatkan emiten.

Dengan ketatnya kriteria yang ditetapkan dan pihak penyelenggara award yang kredibel, logikanya perusahaan yang memenangkan award akan terhindar dari praktik-praktik yang tidak etis seperti manajemen laba. Sayangnya penulis belum menemukan penelitian sebelumnya yang menjadikan variabel award sebagai variabel yang berpengaruh terhadap mana-jemen laba. Sepanjang pengetahuan penulis, bisa dikatakan bahwa ini adalah penelitian pertama yang menggunakan variabel award CSR dan GCG dan pengaruhnya terhadap manajemen laba.

\section{Manajemen Laba}

Konsep manajemen laba menurut Jones (1991) terdiri atas akrual diskresioner (discretionary accrual), yaitu tingkat akrual yang tidak wajar dan non-discretionary accrual, yaitu tingkat akrual yang wajar. Discretionary accrual adalah penga-kuan laba akrual atau beban yang bebas, tidak diatur, dan merupakan pilihan kebijakan manajemen sehingga dapat dimanipulasi sesuai dengan kebijakan manajer, sedangkan non-discretionary accrual adalah pengakuan laba akrual yang wajar dan mengikuti standar atau prinsip akuntansi umum, dapat diterangkan oleh variasi kondisi ekonomi perusahaan, misalnya depresiasi akan meningkat ketika aset bertambah. Ada tiga fenomena (kondisi) ekonomi yang dapat mempengaruhi non-discretionary accrual yaitu aset, perubahan pendapatan, dan Property Plant and Equipment (PPE) (Jones, 1991). Manipulasi laba dapat diindikasikan terjadi apabila discretionary 
accrual abnormal atau aneh. Perusahaan yang melakukan manajemen laba akrual lebih mudah diketahui oleh regulator dan audit.

Roychowdhury (2006) membagi kegiatan manajemen laba menjadi manipulatif akrual (accrual manipulative) di mana manajer mengelola laba dengan memani-pulasi laporan secara akrual tanpa konsekuensi terhadap arus kas langsung dan manipulasi aktivitas sesungguhnya (real activities manipulation) yang mana tindakan ini sebenarnya menyimpang dari etika bisnis yang normal dan hal ini dilakukan dengan tujuan utama untuk memenuhi ambang batas pendapatan tertentu.

\section{Good Corporate Governance (GCG)}

GCG atau dalam Bahasa Indonesia dikenal dengan istilah "tata kelola perusahaan yang baik" adalah suatu proses dan struktur yang dipakai oleh unsur perusahaan (pemilik modal atau pemegang saham, komisaris, direksi dan dewan pengawas) agar dalam jangka panjang keberhasilan dan akuntabilitas nilai pemegang saham meningkat dengan tetap mempedulikan kepentingan stakeholder lainnya sesuai dengan peraturan perundangan dan nilai etika (Sutedi, 2011). Menurut Tunggal (2013), GCG adalah sistem yang mengatur, mengelola dan mengawasi suatu proses pengendalian usaha guna meningkatkan harga saham disamping juga sebagai bentuk perhatian kepara para pemangku kepentingan, karya-wan dan masyarakat sekitar. Disamping itu, GCG adalah system yang mengatur dan mengendalikan perusahaan guna mencip-takan nilai tambah (value added) bagi semua pihak (Monks \& Minow, 2003).

Konsep ini menekankan pada 2 (dua) hal, yaitu pertama pentingnya hak pemegang saham untuk mendapatkan informasi yang valid dan tepat waktu, dan yang kedua adalah perusahaan wajib mengungkapkan (disclosure) secara akurat, tepat waktu, transparan terhadap seluruh informasi kepemilikan dan kinerja perusahaan. Dengan demikian, penerapan GCG dipercaya dapat meningkatkan nilai perusahaan. Praktik GCG antara lain meliputi keberadaan komisaris independen, kepemilikan manajerial, kepemilikan institusional dan kualitas audit.

Konsep GCG dilatarbelakangi oleh pemisahan antara pemilik dan agen (manager) sebagai pengendali perusahaan. Dalam mewujudkan tata kelola perusahaan yang baik diperlukan pemisahan antara fungsi kepemilikan dan pengendalian perusahaan (Jensen \& Meckling, 1976). Oleh karena itu, diharapkan dengan penerapan tata kelola perusahaan yang baik (GCG) dapat mengurangi praktik manajemen laba sehingga didapatkan hipotesis berikut (H1): Penerapan tata kelola perusahaan yang baik berpengaruh negatif terhadap praktik manajemen laba.

\section{Corporate Social Responsibility (CSR)}

Pada prinsipnya CSR merupakan tang-gung jawab perusahaan terhadap para stakeholder-nya (pemangku kepentingan), termasuk terhadap para shareholder (pemegang saham). Pengertian CSR secara global adalah komitmen perusahaan dalam melaksanakan tanggung jawabnya terhadap seluruh pemangku kepentingan, termasuk pemilik dan para pemegang saham, dalam segala aspek operasional perusahaan CSR menetapkan bahwa dalam operasi dan interaksi perusahaan dengan para pemangku 
kepentingan, perusahaan secara sukarela mengintegrasikan masalah ekonomi, sosial, dan lingkungan (Branco \& Rodrigues, 2006). Elkington (1997) menggambarkan triple bottom line sebagai konsep bahwa perusahaan harus memberikan informasi sosial perusahaan tentang dampak ekonomi, sosial dan lingkungan mereka. Konsep triple bottom line menjelaskan bahwa perusahaan dalam menjalankan CSR harus memperhatikan 3P yakni people (manusia), profit (keuntungan), dan planet (lingkungan).

Menurut Hendriyeni (2013) keberhasilan jangka panjang perusahaan memerlukan praktik berkelanjutan yang benar-benar dipahami dan dijalankan oleh seluruh bagian dari perusahaan sampai ke sel-sel terkecilnya. Usaha yang berkelan-jutan identik dengan 3P (people, profit, planet) sehingga perusahaan dalam beroperasi senantiasa berusaha untuk menjaga kesejahteraan manusia dan kelestarian lingkungan dengan tetap menciptakan bisnis yang menghasilkan keuntungan dalam segala kondisi dan berjaya dalam jangka panjang (Hendriyeni, 2013).

CSR merupakan salah satu cara perusahaan untuk mewujudkan komitmennya terhadap para pemangku kepentingan, baik secara etika bisnis maupun secara moral. Melalui kegiatan CSR mereka berusahan mendapatkan legitimasi dari masyarakat. Perusahaan yang berkomitmen secara sosial lebih sedikit melakukan manajemen laba, baik secara akrual diskresioner maupun dengan memanipulasi kegiatan operasionalnya secara nyata (Kim et al., 2012).

T. M. Jones (1995) berpendapat bahwa perusahaan yang berkomitmen melaksanakan CSR lebih terpacu untuk bertindak jujur, dapat dipercaya, dan mengedepankan etika bisnis karena mereka sadar hal itu akan menjadi nilai lebih bagi perusahaan. Oleh karenanya, manajer yang terlibat kegiatan CSR akan enggan untuk mela-kukan manajemen laba karena mereka bertanggung jawab untuk menyajikan laporan keuangan yang transparan. Di sisi lain perusahaan yang memanfa-atkan CSR disclosure untuk memper-kuat reputasi perusahaan, merasa enggan untuk melakukan manajemen laba karena khawatir akan merusak reputasi perusahaannya (Linthicum et al., 2010).

Melalui pendekatan ini maka diharapkan CSR Disclosure dapat meminimalisir masalah keagenan (agency problems), terutama konflik antara pemegang saham mayoritas dan minoritas. Konsekuensinya adalah CSR dapat mengurangi minat para manajer untuk melakukan manajemen laba. Dengan demikian, diharapkan terjadi hubungan negatif antara CSR dengan paktik manajemen laba sehingga didapatkan hipotesis berikut (H2) CSR berpengaruh negatif terhadap praktik manajemen laba perusahaan.

\section{Penghargaan (award)}

Ajang award yang diselenggarakan oleh penyelenggara yang kredibel memberikan persyaratan yang ketat bagi perusahaan yang akan mengikuti ajang tersebut dan seleksi pemilihan pemenangnyapun dilakukan dengan ketat berdasarkan kriteria-kriteria yang telah ditetapkan. Pemenang atau perusahaan yang menerima award diharapkan adalah yang benar-benar memperhatikan seluruh pemangku kepentingannya dan tidak hanya mengejar keuntungan semata. 
Iriyadi (2019) merekomendasikan agar para pemangku kepentingan termasuk regulator mewajibkan perusahaan untuk mengikuti kompetisi yang memberikan award di bidang Annual Report dan GCG. Hal ini dimaksudkan untuk mencegah manajemen laba karena sesuai hasil penelitiannya didapatkan bukti bahwa variable award merupakan salah satu faktor penting yang mencegah manajemen laba (Iriyadi, 2019).

Kriteria penilaian terhadap award yang dipakai dalam penelitian ini yang diantaranya meliputi faktor Good Corporate Governance dan transparansi diharapkan dapat menghasilkan para pemenang yaitu para perusahaan yang memiliki kualitas laporan keuangan yang tinggi dengan praktik manajemen laba yang rendah.

\section{METODE RISET}

Jumlah sampel penelitian yang digunakan untuk penelitian ini adalah sesuai dengan data perusahaan manufaktur yang terdaftar di BEI per tanggal 21 September 2020. Data dicek dan diunduh dari website BEI pada tanggal 21 September 2020 dan hasilnya seperti terlihat pada tabel berikut ini:

Tabel 1. Sampel Penelitian - Perusahaan Manufaktur

\begin{tabular}{lcc}
\hline Total listed company & 709 & \\
\hline Manufacture company: & & \\
Basic industry \& chemical & 80 & \\
Consumer goods & 61 & \\
Miscellaneous industry & 52 & \\
Total manufacture listed & & 193 \\
\hline \multicolumn{3}{c}{ Sumber: website BEI (2020) }
\end{tabular}

Jenis data yang digunakan dalam penelitian ini adalah data sekunder, berupa:

1. Data Keuangan

Data keuangan perusahaan/ laporan keuangan dan laporan tahunan (annual report) perusahaan dikumpulkan melalui website masing-masing perusahaan yang diteliti dan/ atau melalui website Bursa Efek Indonesia. Data keuangan yang dikumpulkan adalah dari tahun 2013 sampai dengan tahun 2019.

2. Data award

Data award yang diterima oleh perusahaan yang diteliti diperoleh dari berita yang beredar di internet, website penyelenggara Award, website perusahaan yang diteliti dan annual report yang diterbitkan oleh perusahaan yang diteliti. Data award yang dikumpulkan adalah award yang diterima perusahaan dari tahun 2015 sampai dengan tahun 2019.

Proksi yang digunakan untuk mengukur CSR dan Tata Kelola adalah award yang diterima oleh perusahaan yang diteliti selama periode tahun 2015 sampai tahun 2019. Award yang diterima perusahaan diberi skor 1 (satu) dan skor 0 (nol) apabila tidak menerima award. Proksi yang digunakan untuk mengukur manajemen laba dalam penelitian ini adalah Accrual Earnings Management (AEM) dan Real Earnings Management (REM). AEM sebagai dependent variable dalam penelitian ini adalah 
nilai discretionary accrual yang merupakan nilai absolut karena manajemen laba dapat terdiri dari akrual penambah ataupun penurunan pendapatan, dan akrual dapat dimodifikasi seiring waktu dan berubah arah. Dan sesuai dengan ketersediaan dan kelengkapan data keuangan yang diperolah, untuk mengukur REM sebagai dependent variable menggunakan riil manajemen yang dilakukan melalui aliran operasi kas.

Penelitian ini juga memakai variabel kontrol yang terdiri dari:

1. Penggunaan Kantor Akuntan Publik (KAP) yang termasuk "the Big 4"

The big four merupakan kelompok empat perusahaan jasa professional terbesar di dunia yang memberikan jasa terkait akuntansi, diantaranya audit laporan keuangan, penjaminan, perpajakan, konsultasi manajemen, advisori, aktuaria, dan keuangan korporasi (Empat Besar (firma audit), 2019). Masyarakat memandang bahwa KAP the big four mempunyai tim auditor yang berkualitas tinggi sehingga dapat mencegah manajemen laba (Sanjaya, 2008).

2. Ukuran perusahaan

Ukuran perusahaan yang dipakai dalam penelitian ini diukur dengan logaritma natural dari total asset perusahaan dengan rumus Ln (total asset). Prior et al. (2008) membuktikan adanya hubungan positif antara manajemen laba dengan CSR sedangkan Dechow \& Dichev (2002) menemukan bukti bahwa perusahaan yang lebih besar cenderung beroperasi dengan stabil dan melaporkan discretionary accruals yang lebih kecil.

3. Return on Asset (ROA)

ROA merupakan salah satu indikator kondisi kesehatan perusahaan yang digunakan untuk mengukur kinerja keuangan perusahaan dengan melihat nilai perbandingan angka item pada laporan keuangan, dengan rumus: ROA = Net Income/Total Assets

Hasil penelitian yang dilakukan oleh Orlitzky et al. (2003) menunjukkan bahwa ROA terpapar oleh alokasi diskresioner pada modal. Model yang dipakai untuk mengukur manajemen laba akrual adalah Modified Jones Model yang dijelaskan dalam Dechow et al. (1995) yaitu sebagai berikut:

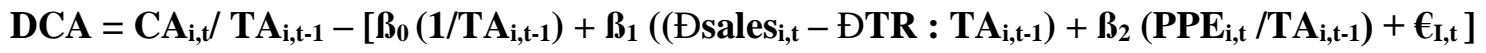

Di mana DCA adalah Discretionary Current Accruals, sedangkan CA adalah Current Accrual; TA $_{\mathrm{t}-1}$ merupakan total asset tahun sebelumnya, Đsales merupakan selisih penjualan tahun ini dengan tahun sebelumnya, PPE adalah Property Plant and Equipment, ĐTR merupakan seli-sih piutang penjualan tahun ini dengan tahun sebelumnya. Abnormal DCA selanjutnya disebut sebagai Accrual Earnings Management (AEM).

Regresi berikut dipakai untuk menguji hipotesis ( $\mathrm{H} 1$ dan $\mathrm{H} 2)$ dan mempelajari hubungan antara manajemen laba dengan CSR dan GCG dengan memakai beberapa variabel kontrol:

$$
\mathrm{AEM}=\mathrm{a}_{0}+\mathrm{b}_{1} \mathrm{GCG}+\mathrm{b}_{2} \mathrm{CSR}+\mathrm{b}_{3} \mathrm{Big} 4+\mathrm{b}_{4} \mathrm{ROA}+\mathrm{b}_{5} \mathrm{Size}+\mathrm{e}
$$


Di mana AEM adalah Accrual Earnings Management (nilai abnormal DCA); GCG merupakan variabel tata kelola yang baik (award GCG); CSR merupakan variabel CSR (award CSR) dan Big4 merupakan variabel kontrol - KAP yang dipakai termasuk "the big 4" dan ROA sebagai variabel kontrol - ROA, sedangkan size adalah variabel kontrol - ukuran perusahaan (Ln total asset).

Model yang dipakai untuk mengukur REM dalam penelitian ini adalah sebagai berikut (Roychowdhury, 2006):

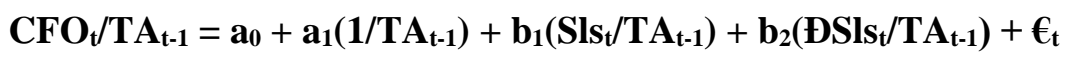

Di mana CFO adalah Cash Flow from Operation, $\mathrm{TA}_{t-1}$ merupakan total asset tahun sebelumnya; Đsales adalah selisih penjualan tahun ini dengan tahun sebelumnya.

Regresi berikut dipakai untuk menguji hipotesis (H1 dan $\mathrm{H} 2)$ dan mempelajari hubungan antara manajemen laba riil yang dilakukan melalui aliran operasi kas dengan CSR dan GCG dengan memakai beberapa variabel kontrol:

\section{REM $=a_{0}+b_{1}$ GCG $+b_{2}$ CSR $+b_{3} \operatorname{Big} 4+b_{4}$ ROA $+b_{5}$ Size $+e$}

Di mana REM adalah Real Earnings Management; GCG merupakan variabel tata kelola yang baik (award GCG); CSR merupakan variabel CSR (award CSR) dan Big4 merupakan variabel kontrol KAP yang dipakai termasuk "the big 4" dan ROA sebagai variabel kontrol - ROA, sedangkan size adalah variabel kontrol - ukuran perusahaan (Ln total asset).

\section{HASIL PENELITIAN DAN PEMBAHASAN}

Per tanggal 21 September 2020, terdapat total 709 (tujuh ratus sembilan) perusahaan yang terdaftar di BEI dan sebanyak 193 (seratus sembilan puluh tiga) perusahaan masuk ke dalam kategori manufaktur. Namun setelah dicek secara keseluruhan ternyata tidak semua perusahaan manufaktur tersebut data laporan keuangannya tersedia lengkap untuk periode laporan tahun 2013 sampai dengan 2019 sehingga dengan demikian hanya terdapat 131 (seratus tiga puluh satu) perusahaan saja yang bisa diteliti lebih lanjut. Periode penelitian ini adalah tahun 2015 sampai dengan tahun 2019, namun demikian laporan keuangan yang dibutuhkan adalah periode tahun 2013 sampai dengan 2019 karena untuk perhitungan manajemen laba dibutuhkan laporan keuangan dua tahun sebelumnya.

Berdasarkan data keuangan yang tersedia, data yang relevan diolah dengan memakai program STATA-16. Tabel 2 adalah tabel statistik deskriptif untuk variabel dependen AEM. Hasil uji statistik pada tabel 2 menunjukkan bahwa nilai mean dari manajemen laba akrual (AEM) adalah 0.0885855 atau sekitar $8 \%$. Angka ini mirip dengan hasil penelitian sebelumnya yang dilakukan oleh Kumala \& Siregar (2020) di mana mereka meneliti perusahaan pertambangan di Indonesia dan hasilnya serupa dengan hasil penelitian ini yaitu 8\%. Tabel 3 adalah hasil regresi berganda dengan menggunakan multiple linear regression 
Tabel 2. Statistik Deskriptif - AEM

\begin{tabular}{r|rrrrr} 
Variable & Obs & Mean & Std. Dev. & Min & Max \\
\hline AEM & 655 & .0885855 & .3059759 & -1.44 e-09 & 5.062789 \\
AwardGCG & 655 & .0396947 & .1953901 & 0 & 1 \\
AwardCSR & 655 & .0366412 & .1880229 & 0 & 1 \\
Big4 & 655 & .3358779 & .4726574 & 0 & 1 \\
SIZE & 655 & 21.64463 & 1.634403 & 16.63178 & 26.58678 \\
\hline ROA & 655 & .0536796 & .1638591 & -.9314516 & 2.000957
\end{tabular}

Sumber: hasil pengolahan data dengan STATA

Tabel 3. Hasil Regresi Berganda - AEM

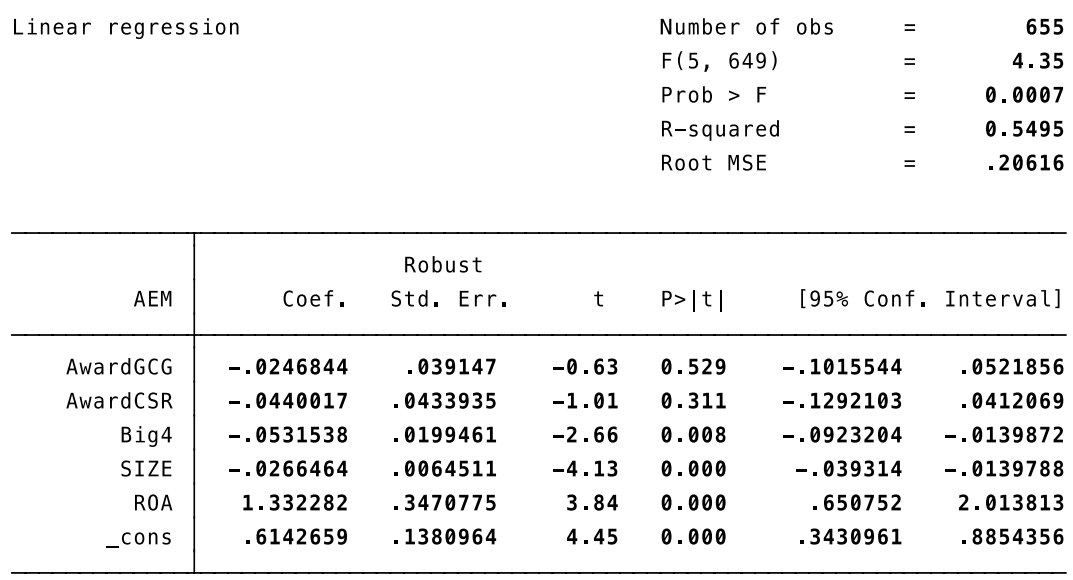

Sumber: hasil regresi berganda dengan STATA

Tabel di atas menampilkan hasil regresi berganda terhadap hipotesis H1 dan H2. Dari hasil regresi di atas menghasilkan nilai $R$-squared sebesar 0.5495 atau sekitar 55\% yang berarti bahwa model yang dipakai dalam penelitian dapat menjelaskan fenomena yang terjadi sebanyak 55\% dan sisanya dipengaruhi oleh faktor di luar model penelitian ini. Hasil regresi menunjukkan hipotesis $\mathrm{H} 1 \mathrm{dan} \mathrm{H} 2$ terbukti, di mana variabel independen GCG dan CSR terbukti berpengaruh negatif terhadap praktik manajemen laba akrual. $\mathrm{H} 1$ dan $\mathrm{H} 2$ diukur dengan menggunakan award yang diterima perusahaan di bidang GCG dan CSR. Namun demikian, jika dilihat dari signifikansinya, baik GCG maupun CSR masih belum terbukti secara signifikan berpengaruh terhadap praktik manajemen laba akrual.

Hasil ini sesuai dengan hasil penelitian yang dilakukan sebelumnya oleh Kumala \& Siregar (2020) yang membuktikan bahwa pengungkapan CSR berpengaruh negatif terhadap praktik manajemen laba. Hasil ini juga sesuai dengan penelitian yang dilakukan di Pakistan oleh (Kamran \& Shah, 2014) di mana mereka berhasil membuktikan bahwa mekanisme GCG berpengaruh negatif dan signifikan terhadap praktik manajemen laba.

Penelitian ini juga menggunakan beberapa variabel kontrol, yaitu ukuran perusahaan, Return on Asset (ROA), dan penggunaan Kantor Akuntan Publik (KAP) yang termasuk "The Big 4”. Dari hasil regresi yang dilakukan didapatkan hasil bahwa dua dari tiga variabel kontrol berpengaruh negatif dan signifikan terhadap praktik manajemen laba akrual, yaitu ukuran perusahaan dan The Big 4; sedangkan 
variabel kontrol "ROA" ternyata berpengaruh positif dan signifikan terhadap praktik manajemen laba akrual. ROA yang berpengaruh positif dan signifikan terhadap praktik manajemen laba ini sesuai dengan hasil penelitian sebelumnya yang dilakukan oleh Cahya Lestari \& Wulandari (2019) yang berhasil membuktikan bahwa ROA berpengaruh positif dan signifikan terhadap praktik manajemen laba.

Sama halnya dengan AEM, untuk REM juga diolah menggunaka STATA-16 dan berikut ini adalah tabel statistik deskriptif dan tabel hasil regresi berganda untuk variabel dependen REM:

Tabel 4. Statistik Deskriptif - REM

\begin{tabular}{r|rrrrr} 
Variable & 0bs & Mean & Std. Dev. & Min & Max \\
\hline REMCF0 & 655 & $1.11 \mathrm{e}-10$ & .3265184 & -4.104512 & 5.416322 \\
AwardGCG & 655 & .0396947 & .1953901 & 0 & 1 \\
AwardCSR & 655 & .0366412 & .1880229 & 0 & 1 \\
Big4 & 655 & .3358779 & .4726574 & 0 & 1 \\
SIZE & 655 & 21.64463 & 1.634403 & 16.63178 & 26.58678 \\
\hline ROA & 655 & .0536796 & .1638591 & -.9314516 & 2.000957
\end{tabular}

Tabel 5. Hasil Regresi Berganda - REM

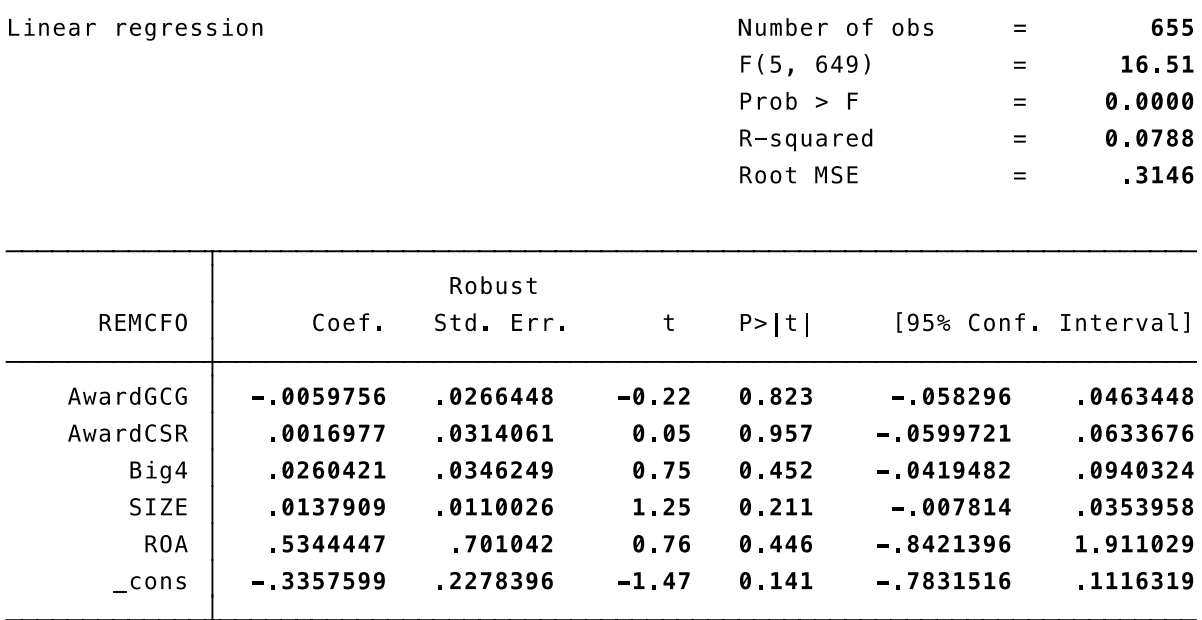

Sumber: hasil regresi berganda dengan STATA

Tabel di atas menampilkan hasil regresi berganda terhadap hipotesis H1 dan H2. Dari hasil regresi di atas menghasilkan nilai $R$-squared sebesar 0.0788 atau sekitar $8 \%$ yang berarti bahwa model yang dipakai dalam penelitian dapat menjelaskan fenomena yang terjadi sebanyak $8 \%$ dan sisanya dipengaruhi oleh faktor di luar model penelitian ini. Hasil regresi menunjukkan hipotesis H1 terbukti, di mana variabel independen GCG terbukti berpengaruh negatif terhadap praktik manajemen laba riil melalui aliran operasi kas; $\mathrm{H} 2$ tidak terbukti di mana CSR memiliki hubungan positif dengan praktik manajemen laba riil melalui aliran operasi kas. Namun jika dilihat dari signifikansinya, baik GCG maupun CSR masih belum terbukti secara signifikan berpengaruh terhadap praktik manajemen laba riil melalui aliran operasi kas. 
Hasil ini mendukung penelitian yang dilakukan di Belanda oleh Calvo (2015) yang menemukan bahwa GCG berpegaruh negatif terhadap praktik manajemen laba riil melalui aliran operasi kas dan penelitian M. Liu et al. (2017) yang menemukan bahwa CSR tidak berpengaruh terhadap praktik manajemen laba riil. Hasil ini juga sesuai dengan hasil penelitian Subekti et al. (2010) yang berhasil membuktikan bahwa perusahaan yang terdaftar di BEI umumnya melakukan praktik manajemen laba berdasarkan aktivitas operasional perusahaan. Hasil ini pun mendukung penelitian yang dilakukan oleh Leuz et al. (2002) yang menemukan bahwa Indonesia (East-Asian Countries) berada dalam zona yang memiliki perlindungan yang lemah terhadap para investor sehingga menyebabkan praktik manajemen laba dapat berjalan.

Hasil regresi berganda juga menunjukkan bahwa seluruh variabel kontrol yang dipakai berpengaruh positif dan tidak signifikan terhadap praktik manajemen laba riil melalui aliran operasi kas. Uji normalitas dan multicollinearity telah dilakukan demi memastikan hasil regresi di atas sesuai dengan asumsi yang berlaku pada asumsi multiple regression. Hasil uji normalitas menunjukkan bahwa data terdistribusi secara normal meskipun belum mencapai tingkat kenormalan 100\%. Hasil uji normalitas dapat dilihat pada grafik 1 dan 2 di bawah ini yang menunjukkan data terdistribusi secara normal.

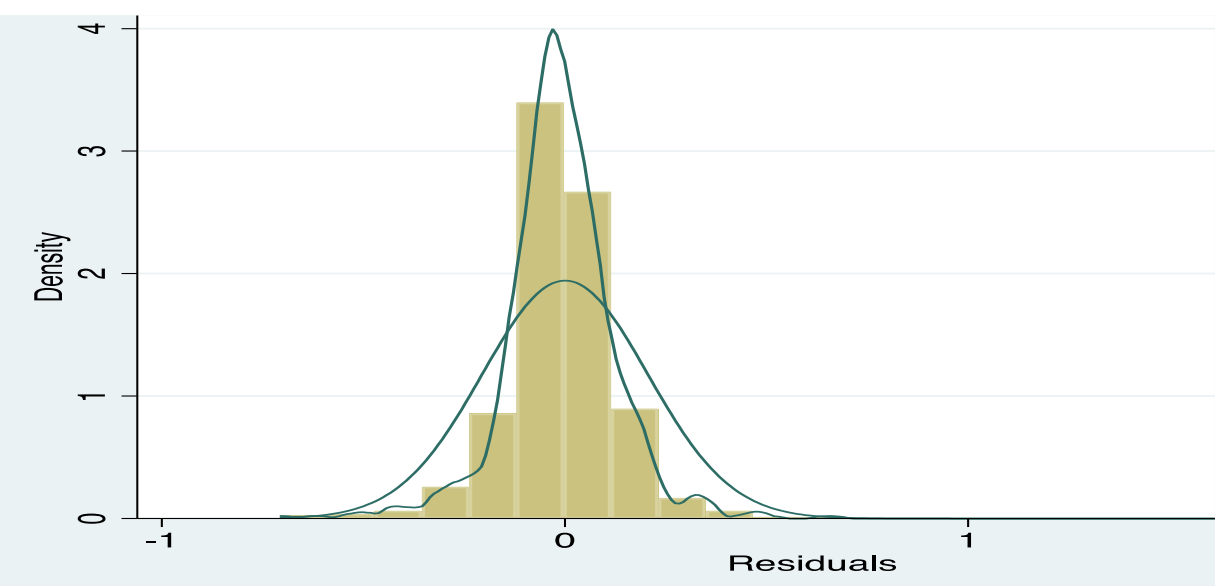

Gambar 1. Grafik Hasil Uji Tes Normalitas - AEM

Sumber: hasil pengolahan dengan STATA

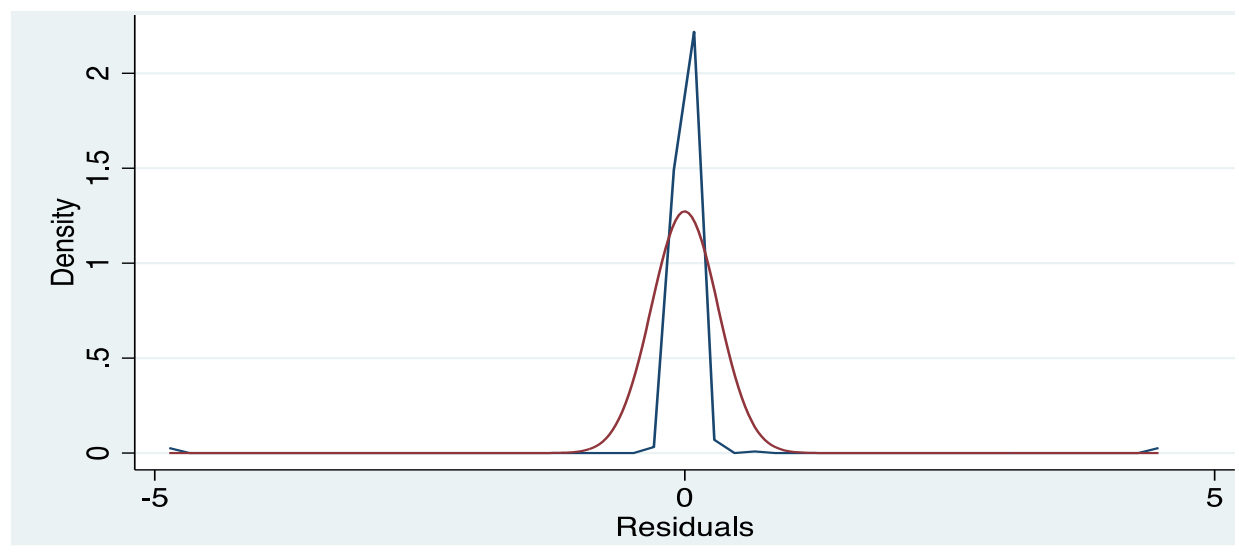

Gambar 2. Grafik Hasil Uji Tes Normalitas - REM

Sumber: hasil pengolahan dengan STATA 
Salah satu asumsi penting lainnya dalam regresi berganda adalah bahwa variabel independen tidak multikolinear sempurna sehingga untuk memastikan bahwa asumsi tersebut dipenuhi, dilakukan Multicollinearity test. Tabel di bawah ini memperlihatkan bahwa model regresi berganda yang dipakai dalam penelitian ini seluruh variabelnya sudah tepat karena nilai VIF untuk seluruh variabel yang diuji di bawah 10 yang artinya seluruh variabel yang digunakan tidak bermasalah.

\begin{tabular}{r|cr}
\multicolumn{3}{c}{ Tabel 6. Hasil Uji Multikolinear } \\
Variable & VIF & 1/VIF \\
\hline SIZE & 1.31 & 0.765303 \\
AwardCSR & 1.19 & 0.840282 \\
Big4 & 1.18 & 0.850925 \\
AwardGCG & 1.12 & 0.896831 \\
ROA & 1.06 & 0.946383 \\
\hline Mean VIF & \multicolumn{3}{|}{} \\
Sumber: hasil pengolahan dengan STATA
\end{tabular}

\section{KESIMPULAN DAN SARAN}

Berdasarkan hasil statistik, terdapat faktor-faktor lain di luar variabel yang digunakan dalam penelitian ini yang mempengaruhi praktik manajemen laba. Hasil penelitian ini menemukan bahwa pemberian award di bidang tata kelola yang baik (GCG) kepada perusahaan belum dapat mengurangi praktik manajemen laba perusahaan secara akrual dan praktik manajemen laba riil melalui aliran operasi kas meskipun pengaruhnya negatif. Dengan demikian, (H1) terbukti, yaitu penerapan tata kelola perusahaan yang baik berpengaruh negatif terhadap praktik manajemen laba, baik manajemen laba akrual maupun manajemen laba riil melalui aliran operasi kas.

Hasil lainnya adalah bahwa pemberian award di bidang CSR kepada perusahaan belum dapat mengurangi praktik manajemen laba perusahaan secara akrual meskipun pengaruhnya negatif. Di sisi lain, pemberian award di bidang CSR tidak berpengaruh terhadap praktik manajemen laba riil yang dilakukan melalui aliran operasi kas. Dengan demikian (H2) yaitu CSR berpengaruh negatif terhadap praktik manajemen laba perusahaan hanya terbukti pada praktik manajemen laba akrual, sedangkan pada manajemen laba riil melalui aliran operasi kas (H2) tidak terbukti.

Dikarenakan keterbatasan data yang diperoleh, maka variabel yang digunakan untuk penelitian ini menjadi terbatas. Namun demikian, penulis yakin bahwa hal tersebut tidak mengurangi kualitas dari hasil penelitian ini dikarenakan perusahaan pemenang award yang dipakai dalam penelitian ini diyakini memiliki kualitas laporan keuangan yang baik dan terhindar dari praktik-praktik yang tidak etis, seperti manajemen laba.

Berdasarkan hasil penelitian di atas, ajang penyelenggaraan award yang berhubungan dengan penerapan tata kelola perusahaan yang baik dan pelaksanaan CSR oleh perusahaan, yang diselenggarakan oleh institusi yang kredibel dan menerapkan sistem penilaian yang komprehensif, serta 
dilaksanakan secara ketat dapat dimanfaatkan untuk mengurangi praktik manajemen laba. Implikasi dari hal ini bahwa Regulator dapat membuat suatu aturan agar seluruh perusahaan, terutama perusahaan yang terdaftar di BEI wajib mengikuti kegiatan pemilihan award di bidang CSR dan GCG. Regulator dapat menetapkan aturan atau kriteria sistem penilaian award agar kualitas pemenang dapat terjaga.

Bagi pemilik perusahaan yang menginginkan agar manajernya tidak melakukan praktik manajemen laba dapat mewajibkan manajernya untuk mengikuti ajang pemberian award di bidang GCG dan CSR dengan memperhatikan pihak penyelenggara yang memiliki reputasi baik dan kredibel. Hasil penelitian ini juga dapat dijadikan salah satu masukan bagi investor dan para pemangku kepentingan lainnya bahwa perusahaan yang mendapatkan award dari lembaga yang kredibel tetap bisa dipertimbangkan untuk menjadi pilihan investasi karena terbukti perusahaan-perusahaan tersebut memiliki praktik GCG dan CSR yang lebih baik dari perusahaan lain.

Untuk penelitian selanjutnya dapat dipilih jenis penghargaan yang lain agar dapat tersedia lebih banyak referensi baik bagi kalangan akademisi maupun para investor. Penelitian sebaiknya dilakukan dengan jumlah sampel yang lebih besar dan periode penelitian yang lebih panjang agar tren praktik manajemen laba dapat lebih diamati, terutama praktik manajemen laba riil yang dalam penelitian ini hasilnya masih kurang maksimal. Penelitian selanjutnya juga dapat dilakukan untuk jenis industri lainnya dan/ atau negara lain yang penerapan GCG dan CSR-nya lebih baik dari Indonesia. 


\section{DAFTAR PUSTAKA}

Ameer, B. (2013). Corporate Governance-Issues and Challenges in Pakistan. International Journal of Academic Research in Business and Social Sciences, 3(4).

Awards Methodology. (2018). CECT Sustainability Award. Retrieved from CECT: https://www.cectsustainabilityawards.com/awards2018.html

Branco, M. (2006). Corporate social responsibility and resource_based perspective. Journal of Business Ethics, 69, 111-132.

Cahya Lestari, K. \&. (2019). Pengaruh Profitabilitas Terhadap Manajemen Laba (Studi Kasus Pada Bank Yang Terdaftar di BEI Tahun 2016-2018). ejournal umm, 2(1).

Calvo, S. G. (2015). Analysing the relationship between Corporate Social Responsibility, Discretionary Accruals and Real Earnings Management. Universiteit Van Amsterdam

Dechow, P. M. (1995). Detecting Earnings Management Author(s): Detecting Earnings Management. Source: The Accounting Review, 70(2).

Dechow, P. M. (2002). The Quality of Accruals and Earnings: The Role of Accrual Estimation Errors. The Accounting Review, 77.

Elkington, J. (1997). Cannibals with forks: The triple bottom line of 21st century business. Capstone/Oxford.

Hendriyeni, N. S. (2013, June 25). People, Planet, Profit, dan Akuntan. Retrieved from PPM Manajemen.

Iriyadi. (2019). Prevention of Earnings Management through Audit Committee and Audit Quality in the Award-Winning and Non-Winning Companies. Journal of Accounting Research, 2(2), 155169.

Jensen, M. C. (1976). Theory of The Firm: Managerial Behavior, Agency Costs and Ownership Structure. Journal of Financial Economics, 3.

Jones, J. J. (1991). Earnings Management During Import Relief Investigations. Journal of Accounting Research, 29(2). 
Kamran, \&. S. (2014). The Impact of Corporate Governance and Ownership Structure on Earnings Management Practices: Evidence from Listed Companies in Pakistan. The Lahore Journal of Economics, 19(2).

Kim, Y. P. (2012). Is earnings quality associated with corporate social responsibility? Accounting Review, 87(3).

Kumala, R. \&. (2020). Corporate social responsibility, family ownership and earnings management: the case of Indonesia. Social Responsibility Journal.

Kumparan. (2020, Jan 13). Beda Kasus Manipulasi Laporan Keuangan Jiwasraya dan Garuda Indonesia. Retrieved from Kumparan.com: https://kumparan.com/kumparanbisnis/beda-kasusmanipulasi-laporan-keuangan-jiwasraya-dan-garuda-indonesia-1sdRq1H9NPG/full

Leuz, C. N. (2002). Investor Protection and Earnings Management: An International Comparison.

Linthicum, C. R. (2010). Social responsibility and corporate reputation: The case of the Arthur Andersen Enron audit failure. Journal of Accounting and Public Policy,, 29(2).

Monks, R. A. (2003). Corporate Governance. Blackwell Publishing.

Negara, K. B. (2011). Peraturan Menteri Negara Badan Usaha Milik Negara Tentang Penerapan Tata Kelola Perusahaan Yang Baik (Good Corporate Governance) Pada Badan Usaha Milik Negara.

Orlitzky, M. S. (2003). Corporate social and financial performance: A meta-analysis. Organization Studies, 24(3).

Pratama, A. M. (2019). Laporan Keuangan Dianulir, Garuda Jadi Rugi? Retrieved from Kompas.Com.

Prior, D. S. (2008). Are socially responsible managers really ethical? Exploring the relationship between earnings management and corporate social responsibility. Corporate Governance: An International Review, 16(3).

Roychowdhury, S. (2006). Earnings management through real activities manipulation. Journal of Accounting and Economics, 42(3), 335-370.

Sanjaya, I. P. (2008). Auditor Eksternal, Komite Audit, dan Manajemen Laba. The Indonesian Journal of Accounting Research (IJAR). 
Subekti, I. W. (2010). The Real and Accruals Earnings Management: Satu Perspektif Dari Teori Prospek. Simposium Nasional Akuntansi XIII Purwokerto.

Sutedi, A. (2011). Good Corporate Governance. Sinar Grafika.

Tunggal, A. W. (2013). Internal Audit dan Good Corporate Governance. Erlangga.

Valencia, C. (2018). IICD CG Award 2018 Bentuk Konsistensi Mendorong Praktik Terbaik dari GCG di Indonesia. Retrieved from kontan.co.id.

Wikipedia. (2019). Empat Besar (firma audit). Retrieved from Wikipedia: https://id.wikipedia.org/wiki/Empat Besar (firma audit) 